\title{
DOLLARS AND DEFICITS: SubSTITUTING FALSE FOR REAL Problems
}

\author{
A. James Meigs
}

Today, people are bewitched, bothered, and bewildered by talk about the twin deficits. However, concentration on the budget deficit and the trade deficit diverts attention from more serious problems: The growth in government spending and the rise of protectionism in international trade.

Both problems impose enormous costs on people of the United States and the rest of the world, and both are extremely difficult to resist. They do not confront us with urgent crises; they are more like a drug habit. They depress world economic growth by impairing the allocation of world resources year in and year out. Both problems are peculiarly intractable and insidious because both provide rich opportunities for public officials and legislators to confer large benefits on a few people while imposing small costs on many. ${ }^{1}$

As economists of the public choice school have taught us, the incentives facing legislators are heavily biased toward increasing spending on individual programs. No legislator expects to be rewarded for voting to cut a program that benefits some of his constituents. We can see that, but we have not yet learned what to do about it. That lack of solution is what makes controlling public spending so difficult.

CatoJournal, Vol. 8, No. 2 (Fall 1988). Copyright $@$ Cato Institute. All rights reserved.

The author is an independent analyst in Princeton, New Jersey, and a former Senior Vice President and Chief Economist at the First Interstate Bancorp. This paper grew out of a topic suggested by Milton Friedman. It benefited greatly from his comments on an early draft. Colin D. Campbell, David I. Meiselman, Mickey D. Levy, Phillip E. Vincent, P. Kenneth Ackbarali, Noreen Doyas, A. Lynn Reaser, Nancy Kane, Rod Swanson, and Steven A. Hess also provided helpful suggestions. The usual caveat applies.

${ }^{1}$ Concentrating on the deficits also diverts attention from other serious problems. For example, Roberts (1988, p. 38) notes that overemphasis on reducing the budget deficit, if necessary by tax increases, diverts attention from monetary policy and a U.S. tax system that discourages private saving. 


\section{Cato Journal}

With their opportunities for increasing expenditures now restricted by a dearth of revenues and by public disapproval of deficits, legislators and bureaucrats find trade protectionism a fruitful source of benefits to sell. Kenneth Brown (1987, p. 97) argues that rent-seeking officials who formulate and administer trade policies prefer, where possible, to work through country-by-country negotiations and quantitative restraints on individual products rather than to take the wholesale route through the General Agreement on Tariffs and Trade. Jan Tumlir (1984) made similar observations.

Nevertheless, popular discussion continues to regard the key problems as twofold: the U.S. budget deficit, as opposed to the level of government spending; and the U.S. trade deficit, as opposed to the level of restraints on international trade. Those deficits look like crises to some observers.

This substitution of false problems for real problems tends to make a large fraction of public policy discussion largely irrelevant. Moreover, measures proposed for reducing the two deficits would make the other problems worse. Tax increases to reduce the budget deficit would weaken what little discipline there now is over expenditures in the federal government. Reducing the trade deficit by retaliating against "unfair" trade practices of other nations or by curbing imports with direct restraints would, by definition, increase protectionism. Finally, reducing imports and increasing exports by manipulating exchange rates would raise a host of additional problems without appreciably reducing pressures for trade protection.

\section{Costs of Government}

The level of government spending, rather than the budget deficit, is the real problem because that level determines what fraction of the community's resources is allocated by the state. However spending is financed, the resources taken for government spending are no longer available for disposition by individuals in the community. The problem is the size of the fraction of the community's total output that is allocated, supposedly on our behalf, by government officials as opposed to the fraction available for individuals to decide how to use.

It is difficult to measure the benefits of governmental activities to society as a whole, not to mention the benefits to the people who contribute the resources. According to George Stigler (1988, p. 9):

Our national income accounts value governmental activities at their cost of operation, so every porkbarrel bridge on an untravelled road is valued at cost along with wise and farseeing actions such as NSF 
grants of money to economists for research designed to eliminate poverty, not least for economists. The growth of functions of government transforms output from goods and services valued by the market to goods and (mostly) services valued by the legislature, the chosen voice of the people.

Furthermore, budgeted expenditures are only a rough guide to the problem of determining who controls the allocation of resources. Governments have become adept at evading spending limits by requiring individuals and firms to make expenditures for, say, antipollution equipment or other governmentally mandated items that never show up in the official budget. Stigler points out that protectionism permits government agencies to achieve large redistributions of income from consumers to certain favored producers without reporting the transfers in the budget or in any governmental account.

Government is a very poor mechanism for allocating resources. The large deadweight losses in redistributing income can actually exceed the net income being transferred. For example, Stigler (1988, p. 10) found that the total deadweight loss of protecting beet sugar farmers is about 18 cents per pound of sugar, or more than four times the gain received by the farmers. He estimates that these and other efforts to redistribute income-one of the principal activities of modern governments-reduce efficiency of the total economy:

Over the past half century, the rate of growth of gross national product per unit of capital and labor employed has declined (let us call this measured efficiency). Partly that decline is attributable to the failure to include the returns in social welfare from research, safety, environmental and income redistribution policies. Surely another large part of the decrease in measured efficiency is due to the large and still rising deadweight losses included in carrying out these social welfare programs [Stigler 1988, p. 10].

If we want to facilitate economic growth through fiscal policy, there are two possible courses of action. The first is to improve the government's allocation-decision machinery. Experience and public choice economics indicate that this approach is unlikely to accomplish very much. The second course is to reduce the share of national resources processed through the federal government's creaky machinery. That course was proposed in the 1981 Reagan Economic Recovery Program but was not fully carried through. ${ }^{2}$

Reducing the share of government spending in total gross national product would increase the share of goods and services valued by

${ }^{2}$ The Reagan administration succeeded in slowing growth of the share of Federal expenditures in gross national product, but the share was still larger in the administration's final year than in its first year. 


\section{Cato Journal}

the market and would reduce the share valued by the legislature and government agencies. The resulting improvement in allocation of resources would make it possible for growth rates of total output, consumption, and saving to increase.

\section{Why Is Spending so Difficult to Control?}

Every year, it seems, we witness the pre-Christmas budget charade. Public discussion focuses on the budget deficit as though it were the object of the exercise, while paying little attention to the multitude of decisions allocating a large chunk of the GNP. This charade is an excellent example of how the deficit diverts attention from more important problems.

The year-end frenzy mainly reveals the incapacity of Congress to make rational budget decisions. Congress demonstrates that it does not know how to decide what share of national income should be allocated by the federal government. It further demonstrates that it has no system for allocating total expenditures among the various functions of govenment other than by bargaining among interest groups and by logrolling. No wonder financial markets around the world have displayed a decline in confidence in the U.S. economy and its managers.

The Congressional Budget and Impoundment Control Act of 1974 was supposed to give Congress the tools for managing the budget in a more business-like way. It succeeded only in spreading a layer of intricate machinery over a giant swap meet. Congressional budgeting has not always been such a tawdry business. Something happened during the 1960s and 1970s to break down a disciplined system that had kept the budget roughly in balance for many years.

Allen Schick (1983) and his collaborators argue in their book, Making Economic Policy in Congress, that strong committee chairmen from both parties formerly viewed themselves as guardians of the public purse. They oversaw budgets that grew incrementally from year to year as they distributed the annual expected increase in revenue resulting from economic growth among the various departments and functions of the federal government. But they did not attempt to distribute more revenue than they expected the tax system to yield.

Internal discipline began to erode in the Congress during the late 1960 s with the opening up of the budget process, the demands for a greater social role for government, the growing independence of individual members of Congress, the proliferation of new committees and subcommittees, and the decline in the influence of party 
leadership. As Schick (1983, p. 258) says, "Many of the reforms that 'democratized' Congress in the late 1960s and early 1970s opened it to increased pressure for benefits from the federal government." These changes cannot easily be reversed.

In spite of this decay and inefficiency in Congress, the budget's growth rate was reduced during President Reagan's administration. How was this accomplished? I believe the key step was to deprive Congress of revenues for new programs. One consequence was a larger deficit for a while, maybe a long while. Another consequence was a brake on growth of federal spending. In former times, the possibility of running a deficit made government spending larger than it otherwise would have been. Today, the deficit is large enough to embarrass Congress into exerting more restraint on spending than it otherwise would.

No matter how pitifully members of Congress and lobbyists may writhe and wail today, the money for bold new spending programs simply is not in sight, unless other programs are cut or the public can be persuaded to accept tax increases. ${ }^{3}$ In his paper, "The Domestic Budget after Gramm-Rudman-and after Reagan," John Weicher (1987, p. 270) says, "The tax reform passed in 1986 will make future tax increases more obvious and, therefore, more difficult politically; the continuing large budget deficits will put downward pressures on federal spending." I would add that indexing personal income tax exemptions and rates to inflation, which was approved in the 1981 tax bill, put further downward pressure on spending by reducing the inflation-revenue dividends produced by bracket creep. This pressure means that the deficit and public resistance to tax increases are now the most effective constraints we have over government spending.

Increasing taxes to reduce the deficit would weaken restraint on spending-a high price to pay. Yet many people in the business community and the economics profession disagree. The editors of Fortune (1987, p. 36), for example, say, "It would be wonderful if the budget deficit could be narrowed without raising taxes. Wonderful but impossible. Politicians of both parties demand more taxes as the price for less spending." To say that politicians demand more taxes should not surprise anyone, for politicians of both parties are in the business of providing benefits to specific groups of constituents.

\footnotetext{
${ }^{3} \mathrm{~A}$ Wall Street Journal story on a congressional vote to override President Reagan's veto of a highway bill said, for example, "While the Democrats had the muscle to save a traditional program like highway spending, it has become almost impossible, politically and economically, to launch big new spending programs." And, later in the same piece, "Democrats feel obliged, along with the President, to continue to bring deficits down" (Birnbaum 1987).
} 


\section{Cato JournaL}

Politicians are desperate for new revenues to distribute-not a compelling argument for giving them what they want.

I believe it is much too optimistic to expect Congress to use proceeds from a tax increase to reduce the deficit. Legislators have little or no incentive to do that. Furthermore, as Congress is now organized, there is no way for a president to enforce an agreement with Congress that expenditures would be cut in exchange for presidential approval of a tax increase, other than to shut down government by refusing to sign a year-end, mammoth, continuing resolution. In 1982 President Reagan thought he had an agreement that Congress would reduce spending by three dollars for every dollar of tax increase that he would approve. Therefore, he agreed to one of the largest tax increases in U.S. history (roughly $\$ 100$ billion), but Congress reneged on the agreement to cut spending (see Niskanen 1988, pp. 77-78). No organized entity in Congress can or will make binding contracts or be held accountable for breaking promises.

A tax increase would only make the federal government bigger, in my opinion, while damaging taxpayers' incentives to work, save, and invest. This dilemma leaves us to consider the costs of tolerating budget deficits, because that is what we may do for some years. I would prefer to see the federal government operate under a balancedbudget rule, but we probably are years away from that. If the deficit is a constraint on growth of federal spending in the meantime, as I believe it is, we must ask whether other costs associated with deficits would offset that one benefit.

\section{Costs of Budget Deficits}

Most public discussion assumes that the costs and dangers of budget deficits are so obvious and so large that deficits must be reduced by any means possible, including tax increases. I disagree. Deficits are bad, but bad compared to what? Some proposed cures could be worse than the disease.

Mickey Levy, David Meiselman, and others have pointed out that the size of the budget deficit tells little about what U.S. fiscal policy is, if the country has a fiscal policy. Levy (1988, p. 58), for example, says, "As residuals of tax revenues and spending, deficits provide only limited and ambiguous information about fiscal policy. Failure to recognize this has tended to oversimplify and mislead fiscal policy analysis, in part by focusing only on the aggregate demand impact of deficit changes." To appraise fiscal policy, therefore, we must examine all component parts on both the expenditure and the revenue sides of the budget. 
Meiselman argues that in order to appraise the costs of government programs we must analyze how the programs are financed. In a general equilibrium framework, he says, we must consider the resource costs of expenditure programs, the distortions in resource allocation introduced by the programs, and the additional distortions and costs introduced by the means of financing. Whether taxes, borrowing, or inflation, each method of financing involves costs and distortions that can be evaluated only by comparing them with the alternatives available. ${ }^{4}$

Therefore, a budget deficit is not automatically the most costly method of financing expenditures. A given dollar change in the deficit could make the United States better off or worse off, depending on which tax or expenditure measures caused the change. Some taxes are worse than others and could be worse than the deficit they are supposed to reduce (see Darby 1987, Levy 1988, Roberts 1988).

If taxes are proposed for reducing the deficit, we must consider their effects on incentives to work, save, and invest. These effects are not trivial, as we found when marginal tax rates were reduced after 1980.

The more conventional discussion of deficits focuses on three major alleged dangers: (1) Deficits are inflationary; (2) changes in deficits stimulate or depress rates of economic expansion; and (3) deficits raise interest rates, which in turn reduce private investment and/or attract capital from abroad, ushering in international adjustment problems that we will discuss later. I believe the evidence for all three arguments is very weak.

Regarding the first charge, I do not know of any evidence that the budget deficit's size has an independent effect on the inflation rate at any given rate of monetary expansion. The Federal Reserve is in charge of the money supply and the inflation rate; however, Federal Reserve chairmen traditionally would rather lecture Congress on the evils of deficits than explain monetary policy. Although inflation came down as deficits went up in the 1980 s, I believe that U.S. longterm interest rates are now higher than they otherwise would be because international investors and borrowers are afraid future U.S. politicians may decide to inflate their way out of the federal government's domestic and international debts. Those concerns are a respectable argument for controlling the deficit's size.

Regarding the second charge, I would argue that conventional macroeconomic theories explaining the impacts of changes in budget deficits on income are now in too much disarray to serve as bases for

${ }^{4}$ Conversations with Professor Meiselman. See also Meiselman (1981). 


\section{Cato Journal}

policy (see Levy 1988, Meiselman 1981). The coup de grace to the orthodox Keynesian analysis of the effects of deficits that many of us were taught when we were young and impressionable came in the early 1980s. While some economists predicted that the deficit would push the economy into an inflationary boom, others feared the deficit actually would prevent the economy from recovering from the 198182 recession. It did neither. Although gallons of ink and buckets of crocodile tears have been expended on the hypothetical dangers of reducing a budget deficit by cutting spending, we need not review those arguments here.

Regarding the third charge, it has been extraordinarily difficult to demonstrate empirically that budget deficits raise interest rates. Many people argue that deficits should raise interest rates, but they have a difficult time proving it. (See Brunner, Levy, Meiselman, Darby, Evans.)

An ingenious recent effort by Paul Wachtel and John Young (1987) demonstrates that announcements of unanticipated changes in projected deficits will affect interest rates in the expected direction on the day of each announcement. Having spent years observing securities dealers and traders at close range, I believe the Wachtel and Young results are consistent with typical dealer reflexes of reacting quickly to new clues about the size of future Treasury auctions. Dealers are preoccupied with flows of funds and securities. However, I need more evidence before concluding that Wachtel and Young have found a clear, dependable relationship between deficits and interest rates, where so many other researchers have failed.

$\mathrm{My}$ reason for not expecting to find strong interest-rate effects of changes in budget deficits is based on analyzing the problem in terms of stocks, rather than in terms of flows. Considering demands and supplies of stocks of assets suggests that current and prospective budget deficits have less influence on interest rates than is implied by many popular arguments for reducing the deficit. As Karl Brunner (1986, p. 715) argued:

The direct link between deficits and interest rates [in conventional flow analysis . . . suggests a massive effect on nominal and real rates of interest. The stock analysis conveys a very different sense. Deficits modify interest rates only indirectly. They gradually increase the stock of real debt and interest rates respond to this increase in the stock. But this increase in the stock relative to the inherited stock is modest compared to the savings-deficit proportion. We should expect therefore a smaller impact on interest rates by deficits than is typically suggested by a flow approach.

Brunner does not mean that the deficit is irrelevant. What matters most is what happens to the size of the stock of real public debt in 
comparison with the real stocks of all other assets. Changes in the U.S. budget deficit have some effects in the expected directions, but the large, predictable, dominant effects on real interest rates that many analysts expect today simply cannot be demonstrated.

\section{Causes and Costs of Trade Deficits}

In reviewing the economic literature and the op-ed pages, I found several main hypotheses used to explain the U.S. trade deficit and to defend various policies for dealing with it. For convenience, I will group them in three general views: the pure trade view, the U.S. capital vacuum cleaner view, and the U.S. investors' paradise view.

In the pure trade view, competitiveness problems, trade barriers abroad, consumer preferences for imported goods, Americans' high propensity to consume both private and public goods, and misaligned exchange rates cause us to import more than we export. Then we are said to borrow abroad to pay for the excess of imports over exports (see Friedman 1987).

In the U.S. capital vacuum cleaner view, which is very popular in other countries, the U.S. budget deficit raises interest rates and pulls in capital from abroad. People in other countries finance the U.S. budget deficit. The United States is then charged with depriving Third World countries and others of the capital they need to develop and work out of their debt problems. ${ }^{5}$ The trade deficit appears as the mirror image of capital flows; goods from other countries are exchanged for U.S. securities and other assets.

However, there are serious flaws in this argument. First, it depends on strong, predictable effects on interest rates that I do not believe can be demonstrated. Second, when the dollar was rising between 1980 and 1985, the budget deficit was blamed for attracting foreign capital and thus for causing the dollar to appreciate (Levy 1988, p. 63). Appreciation of the dollar, in turn, was said to increase the current accounts deficit through its effects on prices of U.S. imports and exports. Therefore, some analysts concluded that it would be necessary to reduce the budget deficit in order to reduce the trade deficit. But when the dollar began to fall again, the budget deficit was blamed. To halt the decline in the dollar, therefore, other analysts, or the same ones, decided that it was imperative for the United States to

${ }^{5}$ For a discussion of possible effects of U.S. deficits on the international debt problem, see Michael Mussa (1984). 


\section{Cato Journal}

reduce its budget deficit. ${ }^{6}$ The same medicine was prescribed for two different problems. Why should budget deficits of roughly the same size cause the dollar to rise at one time and fall at another?

In the U.S. investors' paradise view, the new economic policy regime introduced by the Reagan administration in the 1980 s reduced risks and increased the real after-tax return on investment in the United States. Depressing political and economic developments in the rest of the world at the same time increased the relative attractiveness of the United States for investors from other countries and for American investors, especially commercial banks.

In this view, the capital inflows represent a classic response to the situation of a country whose domestic investment opportunities exceed its domestic savings. Japan and Germany, in contrast, are behaving like countries whose domestic savings exceed their domestic investment opportunities. So, capital flows from Japan and Germany to the United States. Investors, entrepreneurs, and the general public on both sides of the oceans benefit from the capital flows (see Darby 1987 and Economic Report of the President 1985).

The trade deficit may be mutually determined, as Meiselman argues, by both capital flows and competitiveness factors. There is something to the loss-of-competitiveness argument in the case of the U.S. automobile and steel industries. By the slippery canons of balance-ofpayments accounting, a large part of the U.S. trade deficit can be accounted for by net imports of steel and autos. For a long time the managers and unions in these industries did not recognize that they were in a world market. They acted as though they had a secure national market in which all increases in their costs could be passed to their U.S. customers. As in other long-run evolutionary processes, it is difficult now for them to turn back the calendar. U.S. consumers have learned to like, and to trust, imported cars, even in the face of price differentials and trade restraints.

Many U.S. farmers, and the legislators who try to help them with price supports and other subsidies, suffer from a similar lack of realism about the opportunities and problems of participating in a global economy. By pricing U.S. farm products out of world markets, U.S. policymakers have contributed to the decline in our farm exports.

I called the canons of balance-of-payments accounting slippery because changing one or more of the flows is unlikely to change the

\footnotetext{
${ }^{6}$ See Torday (1988) for a typical financial press statement on the twin deficits when the dollar is falling. He writes, "Calls for Washington to boost the dollar through firm action aimed at cutting its budget and trade deficits have been widespread for months but haven't been heeded by the Reagan administration or Congress."
} 
trade deficit by the same amount. If, as I believe, capital flows are the principal determinant of trade flows, reducing the trade deficit in one area such as autos would not change the overall trade deficit. People in other countries would merely use a different package of goods to pay for the U.S, capital assets they want to buy. Americans could, in effect, get new capital from abroad on better terms if the U.S. auto and steel industries were to improve their performance.

\section{Costs of Protectionism}

Advocates of protection argue that trade deficits injure U.S. producers of internationally traded goods. But what is there about the $\mathrm{XYZ}$ industry that would justify the cost of special protection in a highly developed economy like the United States? Unfortunately, people who advocate protection for the $\mathrm{XYZ}$ industry are not required to answer that question; the political system now permits an industry to extract costs of protection from the whole population without weighing the costs and benefits to everybody else. This is where the problems of controlling spending and resisting protectionism are similar.

We are all familiar with studies of the costs to consumers and others for protecting particular industries. Tumlir, however, stressed what I believe is an even more important cost, and one that is little recognized: the cost of interfering with the international price system through quantitative restrictions on trade. According to Tumlir (1984, p. 357):

I find it difficult to work up much interest in tariffs, which both history and theory show to be quite innocuous protective devices, at least when stabilized. Once in place, they do not interfere with changes in relative prices. My main concern is with quantitative restrictions, which have the effect of paralyzing the price system in their area of application.

Unfortunately, quantitative restrictions are the ones that are most in vogue today among politicians, officials, and representatives of producer groups. Politicians and producer groups prefer such restrictions because their costs cannot be measured easily. And, as Kenneth Brown (1987) argues, officials charged with formulating and carrying out trade policy prefer quantitative restrictions because they are labor intensive; these restrictions require endless negotiations and renegotiations with numerous countries to establish and to police quotas on individual products. ${ }^{7}$

${ }^{7}$ See Lardner (1988a, 1988b) for a fascinating account of using quota agreements in a long, costly, futile campaign to protect the U.S. textile and apparel industries from competition with producers in third world and newly industrialized countries. 


\section{Cato Journal}

Other advocates of protectionism argue that large trade deficits cause intolerable changes in U.S. industrial structure. Between 1980 and 1985 some advocates feared that the United States was in danger of losing its industrial base and that we were becoming a nation of short-order cooks and sales clerks. It is now clear that these arguments were grossly overstated. The United States is not being deindustrialized.

However, worldwide changes in industrial structure, or in the location of economic activities, are taking place with the inexorable force of geologic processes, but more rapidly. Exchange rate manipulation and the whole panoply of other protective devices are puny defenses against fast-forward continental drift. In the case of the textile industry, Nancy Kane (1988) argues that we are now seeing shifts in global location in response to technological and other influences that are similar to the regional shifts that occurred within the continental United States much earlier. ${ }^{8}$

In the economic expansion following the 1981-82 recession, U.S. domestic demand grew faster than output. Imports made up the difference. Imports were then blamed for holding down GNP growth. To Americans who were not accustomed to viewing international trade as more than a minor blessing, or annoyance, the surge of imports was unsettling. The times seemed out of joint. Perhaps most mystifying of all was the rise of the dollar on exchange markets. It was easy to consider the "overvalued dollar" as the cause of domestic ills ranging from farm mortgage foreclosures in the Corn Belt to layoffs in the Rust Belt. ${ }^{9}$ The effort to devalue the dollar, which began in 1985 with the Plaza Agreement, was one of the regrettable consequences of overemphasizing the trade deficit.

\section{Attempting to Devalue the Dollar}

Karl Brunner (1986, p. 709) tied exchange rates to the twin deficits in a description of European reactions to U.S. policies:

The [budget] deficit seems to be the cause of double-digit nominal interest rates and the highest real rates since the 1930s. Such interest rates produce apparently an "overvalued dollar" encouraging imports and lowering our exports. This pattern reduces, so we hear, our welfare, as it lowers domestic employment and output below the otherwise achievable level. And the close interdependence of national

${ }^{8}$ See also Brown (1987), Kane (1987), McKenzie (1987), and Tatom (1986).

${ }^{9}$ In 1987 and 1988 the relative rates of growth of U.S. domestic final demand and imports reversed. Although imports remained high by past standards, domestic demand started to grow faster than imports, contributing to a recovery in U.S. manufacturing. 
capital markets transmits the effects of the "high interest policy" pursued by the U.S. government, represented by a "loose" fiscal and "tight" monetary policy, to all major nations. This vision offers European officials an excellent opportunity to blame U.S. policy for their economic troubles.

Although Brunner thought these ideas deserved sarcastic treatment, they apparently were being treated as a serious diagnosis by some members of Congress and inside the Department of Treasury. A blizzard of complaints from U.S. manufacturers and farmers convinced legislators and officials that something must be done about exchange rates-and quickly.

Until concerns about the domestic economy and fears that the trade deficit would lead to more protectionism caused the Reagan administration to begin nudging the dollar down in 1985 , the administration had faithfully observed a policy of not intervening in exchange markets. The nonintervention policy had been announced in the 1981 Reagan Economic Recovery Program. James Baker, secretary of the treasury, announced the reversal of the administration's exchange market policy at the Hotel Plaza in New York City in September 1985. Although the Plaza Agreement met loud world applause, it reminds me of another fateful turn in U.S. policy: the broadening of the U.S. role in Vietnam in 1963.

After American officials encouraged the generals' coup that deposed President Diem in November 1963, the United States effectively took over responsibility for conduct of the war. Richard Holbrooke, who was in Vietnam at the time, later argued that history would hold the United States accountable in one way or another, even for things beyond U.S. control. He said, "Washington, in short, had found the worst possible level of involvement-deep enough to be held responsible, not skillful enough to find a government that could be effective in the war against the Viet Cong" (Holbrooke 1987, p. 46).

In the Plaza Agreement and subsequent agreements, I believe Washington again found the worst possible level of involvementdeep enough to be held responsible, not skillful enough to achieve its objectives in exchange markets. Ever since, the United States and its hapless partners have been lurching from one misadventure in exchange markets to another. Agreement has been piled on agreement as the dollar alternately appears too high or too low to satisfy the officials of the Group of Seven and their critics. Of course, this is not a question of skill alone. The U.S. government is being held accountable for things that are beyond Washington's control, or beyond the control of any government. 


\section{Cato Journal}

The decision to deal with the threat of protectionism by attempting to devalue the dollar is ironic because devaluation could be called "instant protection" itself. Devaluation was intended to discourage imports by increasing the dollar prices of imports and to encourage exports by reducing their prices in foreign currencies. Called "beggar-thy-neighbor" policies during the 1930s, devaluations intended to influence a nation's trade balance were disavowed in the Bretton Woods Agreement at the end of World War II.

Unfortunately, devaluing a currency is not like pulling a master switch that immediately changes prices of imports and exports by the same amounts and in the desired directions. Price effects vary in amounts and timing from product to product, raising new adjustment problems in many markets. Effects on the U.S. trade deficits have been so slow and difficult to see that pressure for protectionism has not diminished.

Exchange rate manipulation, as an alleged substitute for protectionism, has been costly. One cost has been an increase in market uncertainty as exchange traders agonize over each rumor about central bank actions and secret agreements among the Group of Seven. And information about international relative prices that people the world over need for allocating resources is frequently distorted, as it also is distorted by the trade restraints that troubled Tumlir (Meigs 1977, 1987; Tumlir 1984).

If the exchange interventions by the United States and its collaborators had been fully sterilized (that is, if they had been offset by central-bank sales and purchases of domestic assets), they should not have resulted in perceptible changes in domestic monetary policies. But what do we see?

There have been large changes in rates of monetary growth in Japan, Germany, and the United States since the resumption of exchange market intervention in 1985 . We probably will never know how much exchange rate management caused monetary policies to differ from what domestic conditions in each country would have indicated. When the authorities tried to halt the dollar's decline in early 1987, for example, monetary expansion accelerated in Japan and Germany and decelerated in the United States. If these relative trends were to persist, the dollar probably, but not certainly, would eventually rise against the yen and the Deutsche mark. The U.S. authorities might call this rise the result of policy coordination. They have wanted the governments of Japan and West Germany to stimulate their economies while the others have wanted the United States to cool its economy. The tentative evidence indicates that the United States and its partners risk at least some damage to domestic stability 
in exchange for elusive effects on exchange rates and a reduction in the U.S. trade deficit.

\section{Should We Reduce the Capital Inflow?}

Advocates of reducing the U.S. trade deficit should realize that doing so would also reduce the inflow of capital from abroad. Do we really want to do that? If so, why? U.S. governors and mayors who now go to Europe and Japan with delegations of boosters to attract investors may not have heard that they might be boosting the trade deficit by encouraging capital inflows.

Some analysts see the capital inflow as building a debt burden that will depress the living standards for future generations of U.S. citizens. C. Fred Bergsten, for example, was quoted in the Wall Street Journal on December 16, 1987, as saying, "The borrowing binge of the ' 80 s leaves a legacy in terms of annual debt service to foreigners equivalent to about $1.5 \%$ to $2 \%$ of the whole gross national product. That's a permanent cost that will be levied on ourselves, our children and our grandchildren." I disagree. I believe instead that capital inflows from abroad will make future incomes of U.S. residents larger than they would otherwise be.

Benjamin Friedman and others say that much of the foreign capital is used for consumption rather than for investment in productive facilities, leaving Americans with more debt and fewer assets. But this merely reflects the U.S. saving rate, which is lower than saving rates in other countries. If the foreign capital had not come in, would Americans have consumed less, or would they have invested less? The answers are not obvious.

The total capital stock available to U.S. workers and businesses, for any given U.S. saving rate, surely must grow more rapidly with an inflow of capital from abroad than it would without that inflow, even though some imported capital may be consumed instead of being invested in productive facilities. The greater growth of capital stock, therefore, must be reflected in greater growth of total U.S. product (and consumption) than we otherwise would have. So the "burden of debt service" can be paid out of the greater product. How would this be different from the burden of domestic debts? Why does it matter who holds the debt (or equity)?

Foreign owners of businesses in the United States receive the marginal product of their capital, but American workers and various state, local, and federal tax authorities get the rest of the product of the enterprises in which the capital is employed. The total product is certainly greater than it would be without the capital. Moreover, 


\section{Cato Journal}

Japanese and European plant managers are now bringing improved management techniques to our country, just as American managers took improved management techniques to other developing countries in the past. ${ }^{10}$

We may wish that Americans saved more. But the savings rate is not a policy variable to be managed by the federal government. Who knows what is the right level of saving? For believers in free markets the "correct" level of saving is the level resulting from the free exercise of individual preferences in a world in which incentives to save or consume are not distorted by governmental taxing and other activities. This suggests that to minimize such distortions we should examine how our system of taxes and income transfers influences national saving. Some public tax and other policies clearly bias peoples' choices toward consumption and away from saving. This bias is part of the problem of financing public expenditures in the least damaging way.

The growth of consumption reflects the free choices of millions of U.S. residents. Should they be prevented from consuming so much? Should they be forced to save more? Some analysts are so worried about the low U.S. saving rate that they recommend an element of compulsion to increase it. Brian Motley and Marc Charney (1988), for instance, recommend that growth of domestic demand should be slowed to increase domestic saving. Although they believe a decrease in federal expenditures would help, they think that would be difficult to do. "Alternatively," they say, "an increase in taxes or some cutback in federal transfers would reverse the rise in the share of national income accruing to the private sector." It is difficult for me to understand why a rise in the share of national income accruing to the private sector should be deplored. The reasoning of Motley and Charney indicates how preoccupation with deficits could lead to an increase in government spending (assuming I am correct in expecting that a revenue gain would be used for increasing expenditures rather than reducing the deficit).

We could say that Americans are consuming a larger share of current income now than in the past because they have built up vast stocks of human capital and consumer durable goods and because they have great confidence in their prospects. After all, the U.S. economy has provided 19 million new jobs since 1982, while employment in Europe and Japan has been nearly static. The family that borrows to pay for current consumption or for investment in housing,

${ }^{10}$ See Stein (1987) for a similar view of the effects of capital inflows. 
education, or durable goods does take on a burden for the future. But why should this burden be considered irrational?

There is one further argument for discouraging capital inflows or rather for discouraging growth of U.S. indebtedness to people in other countries. The argument, developed forcefully by Benjamin Friedman $(1986,1987)$, is that increasing indebtedness to foreigners has worrisome implications for the independence of U.S. economic policy and for the nation's ability to achieve a rising standard of living. According to Friedman (1986, p. 146) "At the most obvious level, net debtor status implies the need not just to service debt obligations owed abroad but to nurture foreign leaders' confidence in the nation's ability to meet its obligations, and hence their willingness to hold them."

Finally, Friedman (1986) is afraid that foreigners' portfolio preferences will differ from those of American investors and thus will influence asset returns here. In particular, he expects that growing participation of foreign investors in U.S. financial markets will require a greater premium of expected returns on long-term debts over expected returns on short-term debts than has been true in the past.

Friedman's analysis of capital-market effects of foreign investment in the United States does not suggest to me that investors in other countries will impose damaging requirements on the U.S. government or on private borrowers in this country. Foreign investors want the same market conditions that American investors want: stability and predictability in economic policies, and protection of property rights. Foreign investors in U.S. assets must also consider exchange risk, which behooves U.S. policymakers to avoid actions or statements that would undermine confidence in the domestic and international purchasing power of the dollar.

People in financial markets worry more about what governments and central banks may do about a change in a budget deficit or a trade deficit than they do about direct effects of either deficit on corporate earnings or interest rates. Therefore, policymakers should be careful about what they do or say regarding policy changes that could affect the prices of assets held by investors, either domestic or foreign. A sudden loss of investor confidence in the U.S. economy and in its managers could have painful consequences.

A diligent observer of economic policies and financial markets, Michael Keran (1988), argues that three major actions by the U.S. government could, as many analysts fear, trigger the loss of foreign confidence in U.S. economic policy. The first would be any actions that would increase budget deficits. (Investors have already discounted lack of progress in reducing deficits, he says.) This argument 


\section{Cato Journal}

would be all to the good if it makes future congresses more cautious about increasing spending. However, I do not believe policymakers should assume that any or all tax increases that are advertised as intended to reduce budget deficits would sit well with foreign investors. The second policy error that Keran says would shake foreign investors' confidence would be the passage of strongly protectionist trade legislation and a threat to impose capital controls. That policy would be devastating. The third error would be a perception that the Federal Reserve was following an inflationary monetary policy. That policy too would be devastating to investor confidence, not only abroad but also at home.

There is nothing on Keran's list of confidence-shaking policies that should not also apply to American investors. Financial markets at home and abroad are acutely sensitive to real or rumored policy changes that would affect asset values. Policymakers who fail to consider the financial effects of their actions or statements, therefore, will be promptly embarrassed.

\section{Conclusions}

Misplaced concern over budget deficits and trade deficits tempts the government and its official and unofficial advisers to let down their guard against more important problems, especially the growth of government spending and the rise of protectionism in international trade. This same concern tempts them to adopt policies to deal with the deficits that would do more harm than good. Among these harmful policies are proposed tax increases, which would merely increase the size of government and have damaging effects on incentives. Other harmful policies, such as trade restraints and manipulation of exchange rates, would damage U.S. consumers and other members of the global economy.

Controlling the growth in federal spending and the rise of protectionism is difficult because our political system makes it possible for legislators and officials to confer large benefits on well-organized interest groups while imposing small costs on the unorganized majority. As Stigler (1988, p. 11) writes, "It is a small, diffused and unenterprising special interest group that does not find some accommodation in the political scene." Perhaps that is the price of democracy. I hope not.

Exchange rate manipulation is especially damaging, because it increases risks in financial markets and in markets for goods and services by impairing information on international relative prices. It injects whole new realms of uncertainty in financial markets. A cur- 
rency that is subject to direct, arbitrary, unpredictable interventions by governments is less desirable to hold as a store of international purchasing power than it would be if its exchange value were determined solely by market forces. The uncertainty engendered by attempts to manipulate exchange rates may have pushed the dollar below its long-run equilibrium value, giving foreign investors an opportunity to acquire U.S. equities, land, and other direct investments at bargain prices. Thus, U,S. exchange rate policy may actually be contributing to the trade deficit by encouraging the large capital inflow.

\section{References}

Anderson, Gerald H., and Carson, John B. "U.S. Dependence on Foreign Saving." Federal Reserve Bank of Cleveland Economic Commentary, 1 September 1987.

Birnbaum, Jeffrey H. "Democrats Know Spending Pie Won't Get Bigger But Are Determined to Control How It's Sliced." Wall Street Journal, 9 April 1987.

Brown, Kenneth M. "Changes in Industrial Structure and Foreign Competition-The Policy Arguments." In Deficits, Taxes, and Economic Adjustments, pp. 97-128. Edited by Phillip Cagan. Washington, D.C.: American Enterprise Institute, 1987.

Brunner, Karl. "Deficits, Interest Rates, and Monetary Policy." Cato Journal 5 (Winter 1986): 709-26.

Caiden, Naomi. “The Politics of Subtraction." In Making Economic Policy in Congress, pp. 100-30. Edited by Allen Schick. Washington, D.C.: American Enterprise Institute, 1983.

Darby, Michael R. "The Shaky Foundations of the Twin Towers." Remarks at Dartmouth College, 2 October 1987.

Dornbusch, Rudiger W. "The Dollar: How Much Further Depreciation Do We Need?" Federal Reserve Bank of Atlanta Economic Review, 72 (September/October 1987): 2-13.

Dreyer, Jacob S. "The Behavior of the Dollar: Causes and Consequences." In Deficits, Taxes, and Economic Adjustments, pp. 5-62. Edited by Phillip Cagan. Washington, D.C.: American Enterprise Institute, 1987.

Economic Report of the President. Washington, D.C.: Government Printing Office, various years.

Ellwood, John W. "Budget Control in a Redistributive Environment." In Making Economic Policy in Congress, pp. 69-99. Edited by Allen Schick. Washington, D.C.: American Enterprise Institute, 1983.

Evans, Paul. “Do Large Deficits Produce High Interest Rates?” American Economic Review 75 (March 1985): 68-87.

Evans, Paul. "Interest Rates and Expected Future Deficits in the United States." Journal of Political Economy 95 (February 1987): 34-58.

Fortune. "The Budget Deficit: What to Do," 7 December 1987, pp. 36-37. 


\section{Cato JournaL}

Friedman, Benjamin M. Implications of the U.S. Net Capital Inflow. NBER Reprint no. 878. Reprinted from How Open 1s the U.S. Economy? pp. 13761. Edited by R. W. Hafer. Lexington: D.C. Heath and Company, 1986.

Friedman, Benjamin M. "Long-Run Costs of U.S. Fiscal Policy: The International Dimension." Paper prepared for the conference on Ties that Bind: Debts, Deficits, Demography, sponsored by Americans for Generational Equity, Washington, D.C., 10-11 September 1987.

Haberler, Gottfried. "The International Monetary System and Proposals for International Policy Coordination." In Deficits, Taxes, and Economic Adjustments, pp. 63-96. Edited by Phillip Cagan. Washington, D.C.: American Enterprise Institute, 1987.

Holbrooke, Richard. Review of A Death in November, by Ellen J. Hammer. The New Republic, 14 December 1987, pp. 44-47.

Kane, Nancy. "The Myth of Deindustrialization." First Interstate Bancorp Managers' Economic Letter 6, no. 20 (5 October 1987).

Kane, Nancy. Textiles in Transition: Technology, Wages and Industry Relocations in the U.S. Textile Industry, 1880-1930. Westport, Conn.: Greenwood Press, 1988.

Keran, Michael W. "Foreign Influences on the U.S. Economy." The Prudential Economic Review (January 1988).

Lardner, James. "Annals of Business (Global Clothing Industry-Part I)." The New Yorker, 11 January 1988a, pp. 39-73.

Lardner, James. "Annals of Business (Global Clothing Industry-Part II)." The New Yorker, 18 January 1988b, pp. 57-73.

Levy, Mickey D. "Origins and Effects of the Deficit." In Assessing the Reagan Years, pp. 45-69. Edited by David Boaz. Washington, D.C.: Cato Institute, 1988.

McKenzie, Richard B. "The Emergence of the Service Economy: Fact or Artifact?" Cato Institute Policy Analysis no. 93, 27 October 1987.

Meigs, A. James. "The Role of Information Disclosure in International Monetary Policy." In Federal Reserve Policies and Public Disclosure, pp. 4971. Edited by Richard D. Erb. Washington, D.C.: The American Enterprise Institute, 1977.

Meigs, A. James. "The Rise and Fall of the Almighty Dollar: Lobotomy by Committee." The Chapman College Economic \& Business Review, June 1987.

Meiselman, David I. “Tax Cuts, Inflation, and Interest Rates." Statement for Hearings before the Joint Economic Committee, U.S. Congress, on "Tax Policy: Are Tax Cuts Inflationary?" 23 February 1981.

Motley, Brian, and Charney, Marc. "The Saving Shortfall." FRBSF Weekly Letter, 1 January 1988.

Mussa, Michael. "U.S. Macroeconomic Policy and Third World Debt." Cato Journal 4 (Spring/Summer 1984): 81-95.

Niskanen, William A. Reaganomics: An Insider's Account of the Policies and the People. New York: Oxford University Press, 1988.

Roberts, Paul Craig. "Reaganomics and the Crash: The Fallacious Attack on the Twin Towers of Debt." Policy Review, no. 43 (Winter 1988): 38-42. 
Schick, Allen. "The Distributive Congress." In Making Economic Policy in Congress, pp. 257-73. Edited by Allen Schick. Washington, D.C.: American Enterprise Institute, 1983.

Stein, Herbert. "World Economy Doesn't Hang in the Imbalance." Wall Street Journal, 30 December 1987.

Stigler, George J. "The Adam Smith Lecture: The Effect of Government on Economic Efficiency." Business Economics 23 (January 1988):7-13.

Tatom, John A. "Why Has Manufacturing Employment Declined?" Federal Reserve Bank of St. Louis Review 68 (December 1986): 15-25.

Torday, Peter. "Central Banks Set to Counter Dollar Assault." Wall Street Journal, 4 January 1988.

Tumlir, Jan. "Economic Policy for a Stable World Order." Cato Journal 4 (Spring/Summer 1984):355-64.

Wachtel, Paul, and Young, John. "Deficit Announcements and Interest Rates." American Economic Review 77 (December 1987): 1007-12.

Weicher, John C. "The Domestic Budget after Gramm-Rudman-and after Reagan." In Deficits, Taxes, and Economic Adjustments, pp. 243-73. Edited by Phillip Cagan. Washington, D.C.: American Enterprise Institute, 1987. 